\title{
URBAN SPRAWL ENTREPRENEURSHIP AS AN ALTERNATIVE TO DECENTRALIZATION OF THE LABOR MARKET: CASE STUDY ON THE KRAKÓW METROPOLITAN AREA
}

\author{
Justyna Barczyk-Ciuła, Łukasz Satoła ${ }^{凶}$ \\ University of Agriculture in Krakow, Poland
}

\begin{abstract}
The territories of large cities and their neighboring areas are subject to dynamic changes. The process of population movement from city centers to suburban areas has an impact on the economic structures of these areas. A significant portion of economic activity is reallocated with migrating residents to peripheral areas. The aim of the article is to assess the diversity of the urban sprawl entrepreneurship phenomenon in the metropolitan area of Kraków. Analysis has shown that the movement of enterprises related to the population migration takes place to the greatest extent in the zone directly adjacent to Kraków and the Tarnów influence zone. These communes create an attractive environment for residents and encourages them to locate their businesses within that territory.
\end{abstract}

Key words: entrepreneurship, metropolitan areas, suburbanization, urban sprawl

JEL codes: H7, L26, R12, J61

\section{INTRODUCTION}

For a dozen or so years now, the space of big cities has been undergoing transformational processes, which are largely due to the emergence of globalization and regional movements. Mutual integration of countries and regions has led to the beginning of metropolitanization processes in cities - a new phase of urbanization. In this phase there are not only changes in the distribution of the population, but also a transfer of metropolitan functions to the areas influenced by the big city. The change of existing interactions between the core and suburban zones implies socio-economic development of the entire metropolitan area, while the effects of new connections between the city and its neighboring areas are intensified suburbanization.
There are movements within metropolitan areas towards the center - but growth of the suburban zone causes depopulation of the urban core and a population concentration in the urbanized zone.

The influx of people into suburban areas and their daily existence will lead to a dynamic change of suburbs into more complex structures. Increased housing construction and the creation of new spatial infrastructure (mainly transportation) cause the disappearance of the traditional rural or small-town landscape in the areas surrounding the metropolis in favor of amorphous structures with unidentified identity. The growth of cities in a spontaneous, uncontrolled and chaotic way has led to inefficiencies in spatial planning. Local governments abandoned all forms of spatial management for the sake of increasing competition of their 
Barczyk-Ciuła, J., Satoła, Ł. (2020). Urban sprawl entrepreneurship as an alternative to decentralization of the labor market: case study on the Kraków Metropolitan Area. Acta Sci. Pol. Oeconomia 19 (4), 5-14, DOI: 10.22630/ASPE.2020.19.4.35

administrative unit in relation to neighboring municipalities. Suburbanization does not only concern the population. When moving to areas around the city, inhabitants often give up their jobs in the metropolis and relocate their businesses or create new ones in their place of residence or its close vicinity. The distribution of economic units, like that of the population, takes on an uncontrolled character and is not the same in all municipalities. Therefore, the aim of the article is to assess the diversity of the urban sprawl entrepreneurship phenomenon in the metropolitan area of Kraków. The time range of the conducted analyses covered the years 2010-2019.

\section{URBAN SPRAWL AS A SPECIFIC FORM OF SUBURBANIZATION}

Definitions of the metropolis in literature are not unambiguous and put emphasis on various factors determining its designation. Studies of the Union of Polish Metropolises define that it is a "settlement complex of a city (or cities) of knowledge, where more than 500 thousand inhabitants live and more than 50 thousand students study, constituting a European (supranational) transport node. The network of metropolises is an international environment of capital, business and knowledge [own translation]" [Adamowicz 2012]. Bassand [1997], on the other hand, defines the metropolis by a number of the above-mentioned features. Its task is a city with an exceptional specificity, with a population of at least 500 thousand, distinguished by the excellence of services, equipment and institutions. It has unlimited innovative potential in the social, economic and cultural field. In turn, Markowski and Marszał [2006] have identified six criteria on the basis of which Polish cities can be qualified as metropolises. According to them, such a unit should be large and must have between 0.5 and 1 million inhabitants. Moreover, it is a territorial unit highly situated in the national hierarchy, characterized by a high economic and investment potential demonstrated by a developed service sector and the number of scientific units and research and development centers. The authors also pointed out that the city should be highly accessible in spatial scales of various degrees and should act as a center of communication, information and organizational links. Additionally, city leaders in making key decisions should strive to create a network model of management and economy.

Metropolization does not only mean a transformation of the urban space of the city but also a transformation of functional connections of the metropolitan area [Lisowski and Grochowski 2008]. Taking into account the fact that the metropolitan area is a consequence of the considerations on the metropolis it is reasonable to try to define the term. In this case there are also definition problems. According to the study resulting from the project entitled INTIS. Integration and Synergy. Strategy for the Development of the Gdansk Metropolitan Area 2014-2030, the first definition was created for the United Nations conference in Stockholm in 1961. The term was explained as an area which is inhabited by no less than 100 thousand people and has at least one city with a population of at least 50 thousand people, and adjacent units are of a metropolitan nature [Komornicki et al. 2015a]. Trafas [2003] believes that the metropolitan area is: "a spatially continuous, metropolitan settlement system consisting of separate settlement units covering a large city (metropolis) or a compact urban area - as the center (core) of the system and a functionally related urbanized zone with a significant intensity of social, economic and spatial conflicts [own translation]". According to Markowski and Marszal [2006], the definitions of the concept of a metropolitan area, due to the great freedom of terminology, are usually abstract and fuzzy.

Metropolises, as centers of the region, have a significant economic and social potential and concentrate on their territory the most important determinants of economic development, such as: knowledge represented by the presence of universities, highly qualified social capital, favorable conditions for the development of innovation and investments in the most productive sectors [Noworól and Hołuj 2016]. Therefore, they are referred to in the literature as the driving force of the economies of neighboring local government units. Sokol [2004], following Scott's and Stoper's thought, defines the metropolis as the locomotive of the economy. Therefore, the existence of diverse functional connections between metropolises and their surrounding areas leads to increased activation of suburbanization processes. 
The nature of contemporary urbanization, the growing scale of the phenomenon and the area scope of urban expansion, result in the emergence of new settlement systems, the complexity of which blurs the key differences between urban and rural areas [Cohen 2004]. Urbanization of suburbs takes place at a different pace and according to different rules in different countries. However, in some countries, these uncontrolled transformations take the form of a chaotic, violent and lively urbanization, characterized by a lack of spatial order. This phenomenon was defined in the early 1960s as urban sprawl, meaning "a lack of continuity in [urban] expansion" [Clawson 1962]. The literature also defines it as a process of unmanaged structural transformations in suburban municipalities resulting from intensified suburbanization movements [Persky and Wiewel 2012].

The task, according to Brueckner [2000], of urban sprawl in economic terms is to impose greater net marginal costs on public sector entities and households as a consequence of urban decentralization. These costs relate to expenditure on the creation and maintenance of infrastructure and other services for which the local government is responsible, personal transport, as well as urban transport, inefficient use of energy, and many others resulting from the remoteness of human settlements from the city center. However, these are not the only consequences of urban sprawl. In the literature, this process is assessed as definitely negative. Uncontrolled development of suburban areas often leads to spatial chaos and degradation of the landscape. The inflow of population to the area surrounding the metropolis causes a rapid loss of its rural and agricultural character, but also a multi-faceted deagrarianization mainly due to the development of housing, relocation of industry and services and an increase in infrastructural development [Kurek et al. 2014].

Scientists present the consequences of urban sprawl as a bad allocation of resources; however, an increasing number of researchers dealing with suburbanization identify urban sprawl not with negatively evaluated processes, but on the contrary, they find positive economic effects. In their opinion, the transfer of metropolitan functions to suburban areas may be an important factor in maintaining low and stable transport expenditures, reducing overcrowding in the city center and increasing economic efficiency.

In highly centralized cities, a mismatch of the real estate market can be observed. The predominance of demand over supply of land results in an increase in real estate prices and in higher fees resulting from renting residential and office premises [Cheshire and Sheppard 2002]. Therefore, the dispersion of the city into a suburban zone allows to lead jobs out of the costly and overpopulated core of the metropolitan area. The development of ICT networks and the increase in the number of mobile professions is a conducive factor [Anas 2012]. The relocation of the population is usually the phase preceding the decentralization of jobs and the suburbanization of entrepreneurship. The increase of interest in suburban areas in order to run a business has a multifaceted justification and is to a large extent conditioned by lower costs of business location than in the city. On the other hand, according to the theorists dealing with the topic of business location, the choice of the place of operation of a company has a large impact on the development of the social and economic spaces of the urbanized zone, and then on the occurrence of agglomeration and urbanization processes (Fig. 1).

The accumulation of enterprises and the resulting mutual contacts of business entities, as well as relations with customers, increases the attractiveness of the space and result in the concentration of the population. This results in a chain of consequences for the development of the space, as well as stimulates multifaceted structural changes. Originally there is a process of urbanization, and until the agglomeration develops there is an influx of people from the outer zone of the city to the centers. The development of transportation and the lower price of land initiate another stage called suburbanization of entrepreneurship, i.e. the transfer of people and economic entities from the metropolis to suburban areas. The next stage is deurbanization, consisting in overloading metropolitan areas and moving the population to other smaller towns, more distant from the core of the metropolitan area, which are in the urbanization stage. The areas subject to metropolitanization processes differ from each other in size, structure or specificity and are subject to rapid territorial, economic and social changes resulting from the power of influence of the metropolis. 


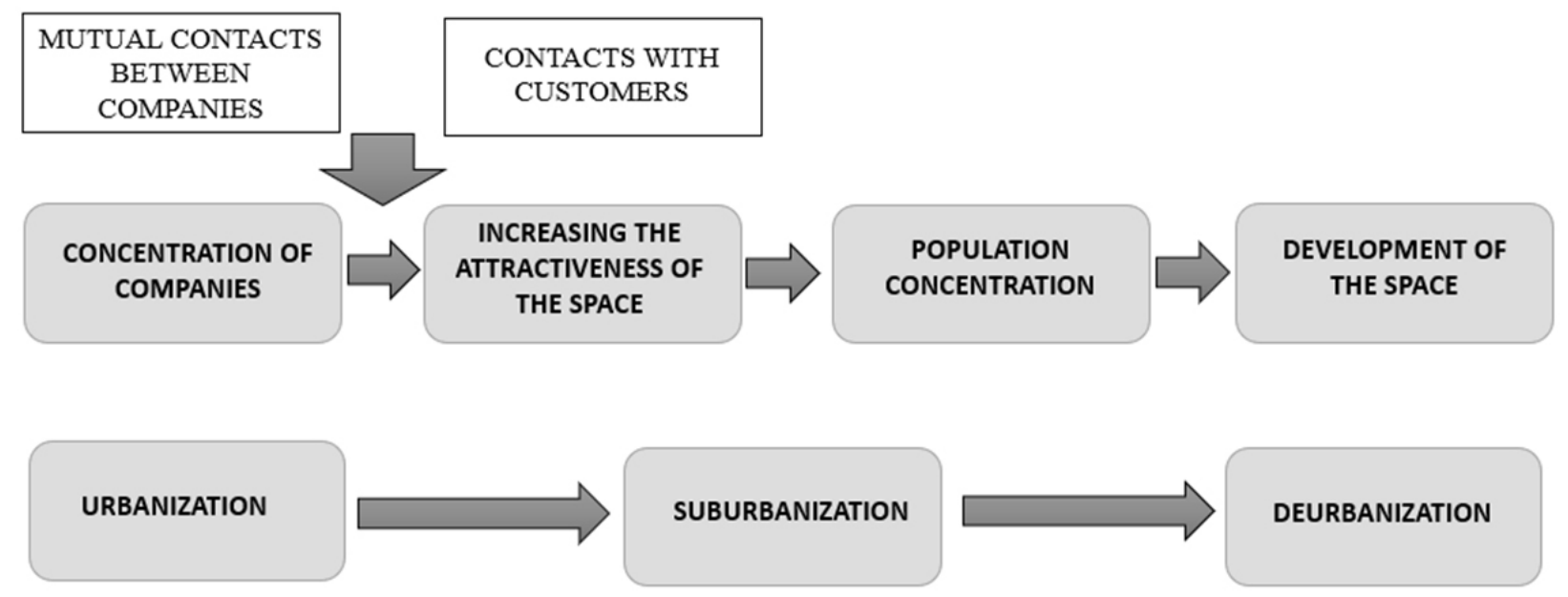

Fig. 1. Influence of business location selection on the agglomeration Source: Authors' own study on the basis of Głębicka and Grewiński [2005].

\section{METHODOLOGY}

According to most sources, the Kraków Metropolitan Area is the third largest metropolitan area in Poland in terms of population. Kraków is the capital of the dynamically developing Małopolska Region; it is a historical metropolis which is subject to strong structural transformations and which continues to develop its metropolitan functions. Being a strong center and creating a europolis, it remains in numerous interactions with neighboring settlement units. Due to the lack of detailed criteria of the functional delimitation of metropolitan areas in Poland, their area coverage is very different. A lack of regulations on the national level causes the literature on the subject to present an ambiguous definition of the scope of influence of the Kraków Metropolitan Area. Therefore, for the purposes of the article, the limits of the territorial range have been determined on the basis of useful report by the Institute of Geography and Spatial Organization Polish Academy of Sciences (Instytut Geografii i Przestrzennego Zagospodarowania im. Stanisława Leszczyckiego Polska Akademia Nauk) entitled Oszacowanie wartości wskaźnika dostępności czasowej na potrzeby dokumentów strategicznych, których postępy sq monitorowane $w$ ramach bazy STRATEG (izochrona drogowa 60 i 90 minut), which was prepared during the third stage of the project entitled Oszacowanie oczekiwanych rezultatów interwencji za pomoca miar dostepności transportowej dostosowanych do potrzeb dokumentów strategicznych i operacyjnych dot. perspektywy finansowej 2014-2020 [Komornicki et al. 2015b]. The isochrone (travel time over a given distance) of $60 \mathrm{~min}$ is identified with the range of the labor market as a contractual limit value for regular employee commuting.

The analysis was carried out in the communes of Małopolskie Voivodeship under the influence of the Kraków Metropolitan Area, which were divided into six zones (Fig. 2):

- Zone K1 "suburban": separated on the basis of National Science Centre (Narodowe Centrum Nauk) grant project by Wojciech Sroka, entitled Rol-nictwo miejskie, jako wyzwanie zrównoważonego rozwoju obszarów metropolitarnych wPolsce - aspekty ekonomiczno-społeczne, środowiskowe $i$ planistyczne, which included 13 municipalities closely adjacent to the city of Kraków;

- Zone K2 "commuting to work": 39 communes designated on the basis of the Spatial Development Plan adopted by the Resolution XV/174/03 of the Małopolskie Voivodeship Regional Assembly of 22 December 2003; 


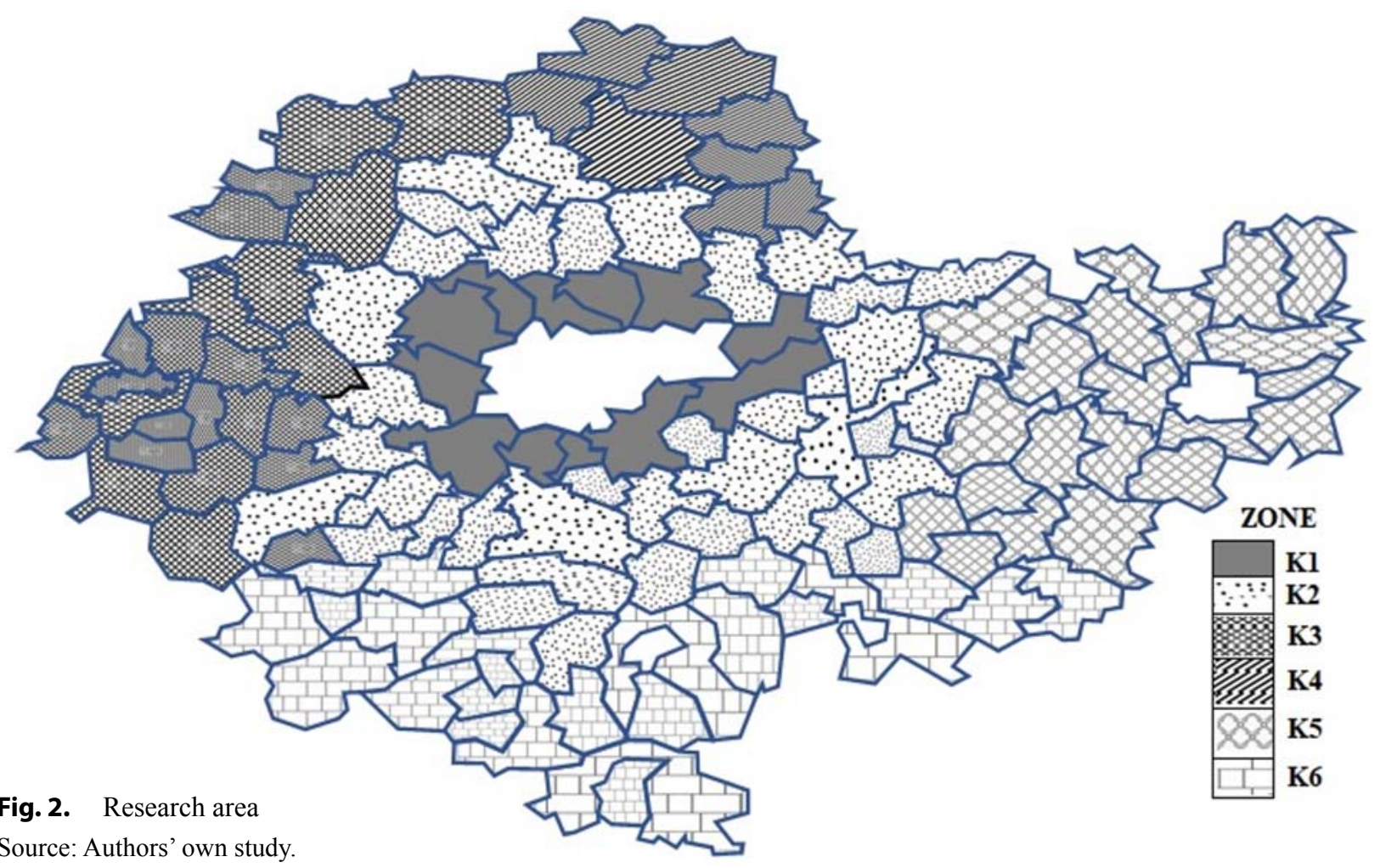

- Zone K3 of the "mixed catchment": determined on the basis of the results of Noworól's and Hołuj's research [2016]. There are 24 communes within its range, which are under the influence of both the city of Kraków and the neighboring cities of the Śląskie Voivodeship;

- Zone K4 of the "agricultural north": determined on the basis of the index of agricultural production space valorization, includes eight communes with the highest values of this index;

- Zone K5 of the "impact of Tarnów": the criterion for designation is the same as for $\mathrm{K} 3$ zone, the zone consists of 19 communes located under the influence of two cities with district rights: Kraków and Tarnów;

- Zone K6 "sub-mountain": determined on the basis of the index of agricultural production space valorization and its terrain component, was included in this group of 25 communes characterized by unfavorable conditions for agricultural production. The research area includes communes that differ in their degree of socio-economic development. This is due to both environmental, cultural and economic conditions, the state of development of a given territory, as well as the strength of integration links between the unit and the center of the area. All the above-mentioned conditions determine the processes of suburbanization of the population as well as entrepreneurship, which is a result of the urban sprawl process. In order to assess the distribution of newly created economic units in the communes under the influence of the Kraków Metropolitan Area, the distribution coefficient called Florence's concentration index $(F)$ and described by the formula was used:

$$
F=\frac{\sum_{i=1}^{k}\left(S_{i}-U_{i}\right)}{100}, \quad S_{i}-U_{i}>0
$$

where:

$S_{i}$ - means the percentage share of the first phenomenon by spatial units,

$U_{i}$ - means the percentage share of the second phenomenon by spatial units,

$i=1,2, \ldots, k-$ number of spatial units. 
Barczyk-Ciuła, J., Satoła, Ł. (2020). Urban sprawl entrepreneurship as an alternative to decentralization of the labor market: case study on the Kraków Metropolitan Area. Acta Sci. Pol. Oeconomia 19 (4), 5-14, DOI: 10.22630/ASPE.2020.19.4.35

The Florence index allows to indicate the degree of distribution of objects in the analyzed space. It assesses the degree of concentration of the examined feature in the territorial unit, as well as indicates the disproportions occurring between particular research areas [Czyż 2016]. The distribution coefficient was calculated for newly registered entities of the national economy taking into account the balance of population migration in the years 2010-2019. The research was conducted on the basis of data from the Statistics Poland (Główny Urząd Statystyczny).

\section{RESULTS OF THE RESEARCH}

Migration of people is a phenomenon known in economic sciences. Among the causes of population movement are often indicated the availability and quality of jobs, the attractiveness of the place of residence, the advantages of the location associated, among others, with well-developed transportation networks [Drejerska et al. 2014]. One of the types of migration is the phenomenon of changing the place of residence by the current residents of cities and settling them outside large urban centers. Such processes have been taking place for many years also in the Małopolskie Voivodeship, including with particular intensity in the Kraków Metropolitan Area.

The phenomena of suburbanization and related population migration are most intense in the vicinity of Kraków. Especially municipalities located to the southeast of Kraków experience a large influx of urban population. The process of population migration from the center is also visible in the communes located in the $\mathrm{K} 2$ zone (commuting to work), but its intensity is lower there. The second area where the urban sprawl phenomenon is visible are the municipalities adjacent to Tarnów, the second most populous city in the voivodeship (Fig. 3).

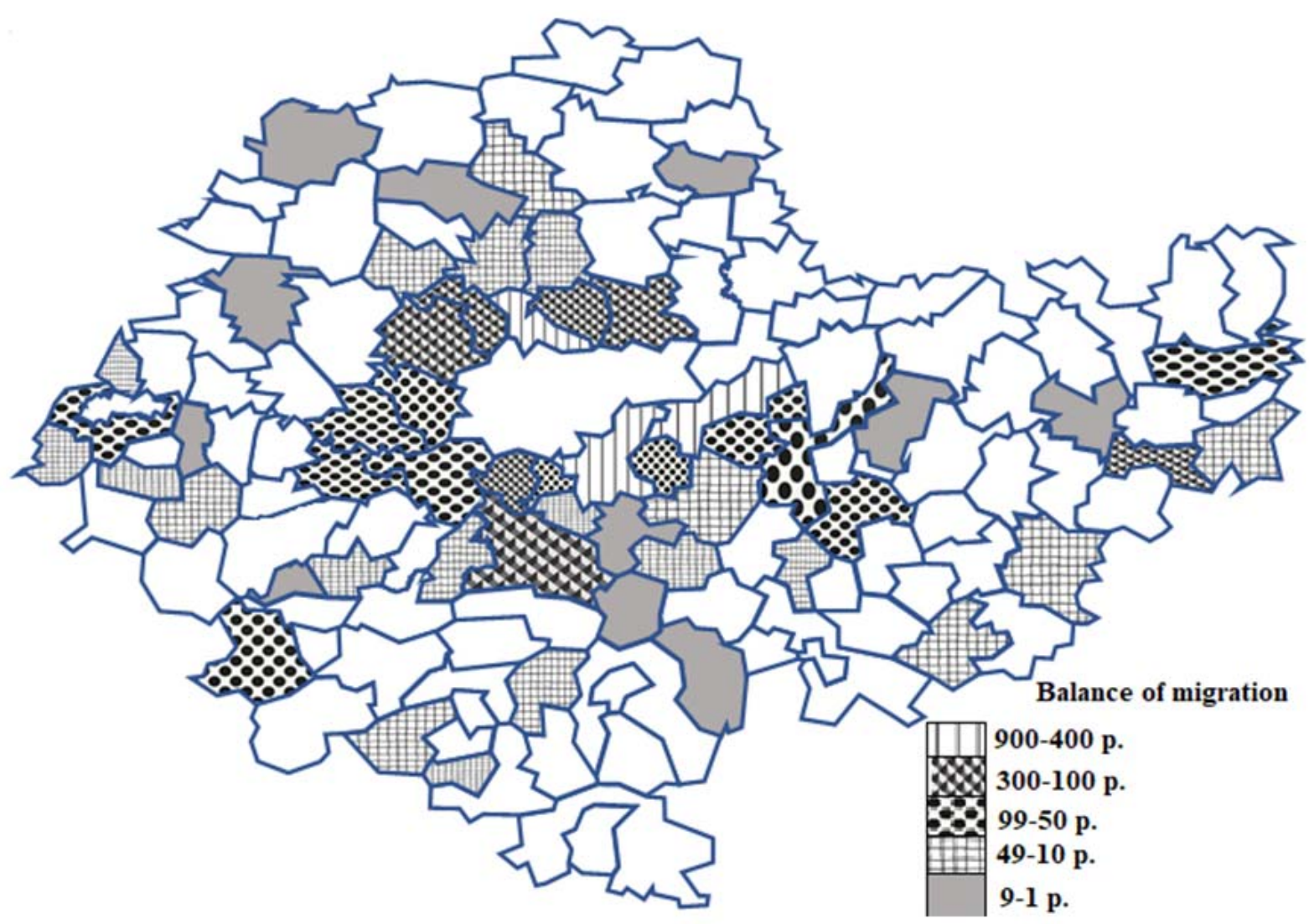

Fig. 3. Positive migration balance in 2019 in the research zone Source: Authors' own study based on Statistics Poland data. 
Barczyk-Ciuła, J., Satoła, Ł. (2020). Urban sprawl entrepreneurship as an alternative to decentralization of the labor market: case study on the Kraków Metropolitan Area. Acta Sci. Pol. Oeconomia 19 (4), 5-14, DOI: 10.22630/ASPE.2020.19.4.35

Taking into account the values of the migration rates from cities, the largest number of people moved from the city to the Tarnów impact zone (K5). In each of the analyzed years, the share of this zone was clearly greater than the others, while in 2018-2019 this difference was particularly high (Table 1 ).

Among the municipalities in the Tarnów impact zone (K5), the process of population migration from cities was most visible in the municipalities of Wierzchosławice and Pleśna. Both these communes are directly adjacent to Tarnów and have good transportation with it. An important, additional advantage of the Wierzchosławice commune is the motorway junction located on its territory. For many entrepreneurs it is a very important argument when locating a business, because it enables efficient delivery of raw materials necessary in the production process and the possibility of quick transport of manufactured products [Glaeser and Kahn 2001, Rakowska 2014].

The creation of new enterprises by people migrating from the cities to the suburban area is also the result of calculating the costs of running a business. Highly urbanized areas, despite providing many facilities for running businesses, also generate higher costs. They are associated with higher rental rates for production and office space, higher rates of taxes and local fees, and often also the need to offer higher remuneration to employees. Suburbanized areas are able to offer much cheaper space for business. Moreover, local authorities wanting to stimulate entrepreneurship apply a tax policy that is favorable to business and residents [Barczyk et al. 2018]. Entrepreneurial behaviors play an important role in shaping the development of a given region; on the other hand, the level of development of a given area may have an impact on decisions concerning the location of economic units [Satoła 2014].

Creating new economic entities on a given territory is proof of the entrepreneurship of the inhabitants and an expression of seeing in the environment opportunities to improve their financial condition. The new production and service entities, through the action of multiplier effects, contribute to the development of areas in which they are located.

New enterprises were created in each Kraków Metropolitan Area zone. Most of them were created in the commuting zone (K2) and the mixed catchment zone (K3). However, in the latter zone, the indicator of entrepreneurship development showed a constant and clear downward trend. By far the lowest level of entrepreneurship was characteristic for units representing the agricultural zone of the north (K4), which in a way confirms the agricultural character of this part of the region (Table 2).

The research conducted with the use of Florence's location index proved the existence of urban sprawl entrepreneurship. This means that the change of location of enterprises occurred as a consequence of the change of residence from an urban center to a village by city residents. The most significant phenomenon of urban sprawl entrepreneurship was observed in the Tarnów impact zone (K5) and in the suburban zone (K1). The average value of Florence's location index at the level of 0.23 means a rather large dispersion of this type of entrepreneurship. It is worth noting, however, that the

Table 1. List of migration indicators for permanent residence from cities by zones of the Kraków Metropolitan Area

\begin{tabular}{lcccccccccc}
\hline Zone & 2010 & 2011 & 2012 & 2013 & 2014 & 2015 & 2016 & 2017 & 2018 & 2019 \\
\hline K1 & 20.5 & 19.8 & 19.8 & 19.2 & 18.9 & 19.0 & 20.2 & 20.1 & 18.4 & 19.1 \\
\hline K2 & 17.9 & 18.4 & 18.2 & 18.5 & 17.8 & 17.7 & 16.8 & 18.0 & 15.3 & 14.3 \\
\hline K3 & 17.6 & 17.2 & 18.0 & 17.3 & 16.9 & 16.6 & 16.5 & 16.1 & 15.6 & 13.4 \\
\hline K4 & 1.7 & 1.8 & 1.4 & 1.6 & 1.9 & 2.1 & 1.9 & 1.9 & 1.6 & 1.3 \\
\hline K5 & 35.3 & 36.2 & 35.7 & 36.5 & 37.7 & 38.6 & 37.7 & 37.6 & 43.0 & 46.9 \\
\hline K6 & 7.0 & 6.6 & 6.8 & 6.9 & 6.9 & 6.0 & 6.9 & 6.3 & 6.0 & 5.1 \\
\hline
\end{tabular}

Source: Authors' own calculations based on Local Data Bank (Bank Danych Lokalnych) of the Statistics Poland data. 
Barczyk-Ciuła, J., Satoła, Ł. (2020). Urban sprawl entrepreneurship as an alternative to decentralization of the labor market: case study on the Kraków Metropolitan Area. Acta Sci. Pol. Oeconomia 19 (4), 5-14, DOI: 10.22630/ASPE.2020.19.4.35

Table 2. List of entrepreneurship share indicators by zones of the Kraków Metropolitan Area

\begin{tabular}{lcccccccccc}
\hline Zone & 2010 & 2011 & 2012 & 2013 & 2014 & 2015 & 2016 & 2017 & 2018 & 2019 \\
\hline K1 & 15.7 & 17.7 & 17.4 & 16.9 & 17.3 & 17.2 & 18.1 & 17.6 & 17.2 & 18.2 \\
\hline K2 & 24.4 & 24.9 & 24.0 & 25.6 & 24.7 & 24.3 & 24.8 & 25.4 & 25.3 & 25.8 \\
\hline K3 & 24.8 & 23.3 & 22.7 & 22.0 & 22.4 & 21.5 & 21.3 & 21.0 & 20.6 & 19.6 \\
\hline K4 & 1.9 & 2.3 & 2.1 & 2.5 & 2.5 & 2.3 & 2.4 & 2.0 & 2.3 & 2.0 \\
\hline K5 & 17.7 & 17.3 & 18.3 & 18.0 & 16.8 & 18.1 & 17.4 & 17.7 & 17.9 & 18.1 \\
\hline K6 & 15.6 & 14.6 & 15.5 & 15.0 & 16.4 & 16.6 & 16.1 & 16.3 & 16.8 & 16.4 \\
\hline
\end{tabular}

Source: Authors' own calculations based on Local Data Bank (Bank Danych Lokalnych) of the Statistics Poland data.

dynamic analysis of the index conducted in the years 2010-2019 makes it possible to state that every year there was a greater concentration of new enterprises as a consequence of urban sprawl processes. This means that there is a limited number of municipalities to which economic entities are transferred as a consequence of earlier migration of residents from large cities to the peripheries (suburban areas). This group of communes is made up of units offering the most attractive offer for residents in terms of accessibility and quality of public services provided [Marks-Bielska et al. 2019].

\section{CONCLUSIONS}

Suburban areas of the metropolis arouse great interest not only among city dwellers, who are more and more willing to choose these areas as their place of residence, but also among entrepreneurs, who in turn perceive them as a chance to reduce the costs of production resources. Both the change of place of residence as well as the location of the company due to the lack of effectiveness of the Polish spatial planning system are characterized by great chaos and spontaneity. These processes show great spatial dynamics disguised as urban sprawl. Many researchers dealing with the subject of suburbanization focus their attention only on the development of the residential function of peripheral areas; however, the territorial distribution of the economic function has also been relocated within several decades.

The conducted research confirmed that within the Kraków Metropolitan Area there is also a process of shifting entrepreneurship from the city to the suburban area. However, this phenomenon assumes a different degree of intensity in individual communes and it depends on socio-economic and cultural conditions. Florence's distribution index indicates a very high degree of distribution of entrepreneurship, which means that the new economic units were poorly concentrated. The relocation of economic entities is understood as a change of spatial orientation and their concentration resulting from the fact of population migration is most noticeable in the zone directly adjacent to Kraków and the areas between the metropolis and the city of Tarnów. Nevertheless, the dynamics of changes in both areas is definitely different.

According to the analyzed data, as the years go by, entrepreneurs are increasingly rarely choosing the location of their enterprise in the municipalities directly bordering on Kraków. It can be assumed that the reason for such a choice is the prestige of these administrative units. Increased attractiveness causes an increase in costs of production factors, and high local tax rates discourage new entrepreneurs from locating their business units. Therefore, business owners are looking for a location generating lower costs. In this case, they may be located between two cities with district rights, i.e. Kraków and Tarnów. Concentration of enterprises in these areas may prove to be a key factor of spatial and economic development at the local level. The presented research does not exhaust the whole problem. A proposal for future research may be to identify the factors of differentiation of the location of enterprises in urban sprawl areas. 


\section{REFERENCES}

Adamowicz, P. (2012). Metropolie regionami kapitału i wiedzy. [In:] Z. Zychowicz (Ed.), Samorząd terytorialny w przestrzeni publicznej. Wydawnictwo Instytutu Rozwoju Regionalnego, Warszawa.

Anas, A. (2012). Discovering the efficiency of urban sprawl. [In:] N. Brooks, K. Donaghy, G-J. Knaap (Eds.), Oxford Handbook of Urban Economics and Planning. Oxford University Press, New York, https://www.doi. org/10.1093/oxfordhb/9780195380620.013.0007

Barczyk, J., Nogieć, M., Sroka, W., Wojewodzic, T. (2018). Pozarolnicza działalność gospodarcza w gminach położonych w zasięgu oddziaływania Krakowskiego Obszaru Metropolitalnego. Roczniki Naukowe Ekonomii Rolnictwa i Rozwoju Obszarów Wiejskich, 105 (1), 47-57.

Bassand, M. (1997). Metropolisation et inegalites sociales. Presses polytechniques et universitaires romandes, Lausanne.

Brueckner, J. (2000). Urban Sprawl: Diagnosis and Remedies. International Regional Science Review, 23 (2), 160-171.

Cheshire, P., Sheppard, S. (2002). The welfare economics of land use planning. Journal of Urban Economics, 52 (2), 242-269.

Clawson, M. (1962). Urban sprawl and speculation in urban land. Land Economics, 38 (2), 99-111.

Cohen, B. (2004). Urban growth in developing countries: A review of current trends and a caution regarding existing forecasts. World Development, 32 (1), 23-51.

Czyż, T. (2016). Metoda wskaźnikowa w geografii społeczno-ekonomicznej. Rozwój Regionalny i Polityka Regionalna, 34, 9-19.

Drejerska, N., Chrzanowska, M., Pomianek, I. (2014). Strefa podmiejska Warszawy. Wybrane zagadnienia. Wydawnictwo SGGW, Warszawa.

Glaeser, E.L., Kahn, M.E. (2001). Decentralized employment and the transformation of the American city. [In:] J.R. Pack, W.G. Gale (Eds.), Brookings-Wharton Papers on Urban Affairs. Vol. 2. Brookings Institution Press, Washington, DC.

Głębicka, K., Grewiński, M. (2005). Polityka spójności społeczno-gospodarczej Unii Europejskiej. Dom Wydawniczy Elipsa, Warszawa.

Komornicki, T., Rosik, P., Śleszyński, P., Stępniak, M. (2015b). Oszacowanie wartości wskaźnika dostępności czasowej na potrzeby dokumentów strategicznych, których postępy są monitorowane w ramach bazy STRATEG (izochrona drogowa 60 i 90 minut). Raport przygotowany w ramach III etapu projektu: „Oszacowanie oczekiwanych rezultatów interwencji za pomocą miar dostępności transportowej dostosowanych do potrzeb dokumentów strategicznych i operacyjnych dot. perspektywy finansowej 2014-2020". Available at www. ewaluacja.gov.pl [accessed 13.12.2020].

Komornicki, T., Zaucha, J., Lipińska, K., Siłka, P. (2015a). Metody współpracy na obszarze metropolitalnym w kontekście Strategii Obszaru Metropolitalnego Gdańsk-Gdynia-Sopot do roku 2030. Warszawa - Gdańsk. Retrieved from https://www.metropoliagdansk.pl/upload/files/podrecznik_wdra\%C5\%BCanie_final.pdf [accessed 05.10.2020].

Kurek, S., Gałka, J., Wójtowicz, M. (2014). Wpływ suburbanizacji na przemiany wybranych struktur demograficznych i powiązań funkcjonalno-przestrzennych w Krakowskim Obszarze Metropolitalnym. Wydawnictwo Naukowe Uniwersytetu Pedagogicznego, Kraków.

Lisowski, A., Grochowski, M. (2008). Procesy suburbanizacji. Uwarunkowania, formy i konsekwencje. [In:] Ekspertyzy do Koncepcji Przestrzennego Zagospodarowania Kraju 2008-2033. Ministerstwo Rozwoju Regionalnego, Warszawa, 221-280.

Markowski, T., Marszał, T. (2006). Metropolie, obszary metropolitalne, metropolizacja. Problemy i pojęcia podstawowe. Komitet Przestrzennego Zagospodarowania Kraju PAN, Warszawa.

Marks-Bielska, R., Wojarska, M., Serocka, I. (2019). Importance of measures taken by local authorities for development of entrepreneurship - a case study of rural municipalities in Poland. [In:] Proceedings of the 2019 International Scientific Conference "Economic Science for Rural Development". No 50. Latvia University of Life Sciences and Technologies, 132-139.

Noworól, A., Hołuj, A. (Eds.). (2016). Społeczno-ekonomiczne przemiany w strefie podmiejskiej miast. Studium przypadku Krakowskiego Obszaru Metropolitalnego. CeDeWu, Warszawa.

Persky, J., Wiewel, J. (2012). Urban Decentraliztion, Suburbanization, and Sprawl: an Equity Perspective. [In:] N. Brooks, K. Donaghy, G-J. Knaap (Eds.), Oxford Handbook of Urban Economics and Planning. Oxford University Press, New York.

Rakowska, J. (2014). Codzienne dojazdy do pracy jako ekonomiczne kryterium rządowych klasyfikacji i delimitacji obszarów (na przykładzie USA i Kanady). Studia Regionalne i Lokalne, 15 (57), 46-59.

Satoła, Ł. (2014). Wpływ polityki podatkowej gmin na poziom przedsiębiorczości (na przykładzie podatku od nieruchomości). Nierówności Społeczne A Wzrost Gospodarczy, (40), 238-247. 
Sokol, M. (2004). City-Regional Governance: on Conceptual Issues. [In:] City Futures. International Conference in Globalization and Urban Change Proceedings. University of Illinois at Chicago, Chicago, https://www.doi. org/10.1093/oxfordhb/9780195380620.013.0008

Trafas, K. (2003). Badania delimitacji obszarów metropolitalnych. Retrieved from http://www.malopolskie. pl/Planowanie/Pliki/seminarium_trafas.pdf [accessed 27.09.2020].
Uchwała Nr XV/174/03 Sejmiku Województwa Małopolskiego z dnia 22 grudnia 2003 roku w sprawie uchwalenia Planu Zagospodarowania Przestrzennego Województwa [Resolution No XV/174/03 of the Małopolskie Voivodeship Regional Assembly of 22 December 2013 on the Voivodeship Spatial Development Plan]. Dz. Urz. Woj. Małopolskiego. Available at www.bip. malopolska.pl [accessed 15.10.2020].

\section{PRZEDSIĘBIORCZOŚĆ URBAN SPRAWL JAKO ALTERNATYWA DECENTRALIZACJI RYNKU PRACY NA PRZYKŁADZIE KRAKOWSKIEGO OBSZARU METROPOLITALNEGO}

\section{STRESZCZENIE}

Obszary dużych miast oraz sąsiadujących z nimi obszarów podlegają dynamicznym zmianom. Procesy przenoszenia się ludności z centrów miast na tereny podmiejskie wywierają wpływ na kształtowanie się struktur ekonomicznych tych obszarów. Część aktywności gospodarczej jest realokowana wraz z migrującymi mieszkańcami na obszary peryferyjne. Celem artykułu jest ocena zróżnicowania zjawiska przedsiębiorczości urban sprawl na obszarze metropolitalnym Krakowa. Analizy wykazały, że przemieszczanie przedsiębiorstw związane z migracją ludności w największym stopniu zachodzi w strefie bezpośrednio sąsiadującej z Krakowem oraz strefie oddziaływania Tarnowa. Gminy te tworzą atrakcyjną ofertę dla mieszkańców oraz sprzyjają lokalizacji przez nich przedsiębiorstw na ich terenie.

Słowa kluczowe: przedsiębiorczość, obszary metropolitalne, suburbanizacja, urban sprawl 